ISSN 1678-3921

Journal homepage: www.embrapa.br/pab

For manuscript submission and journal contents, access: www.scielo.br/pab

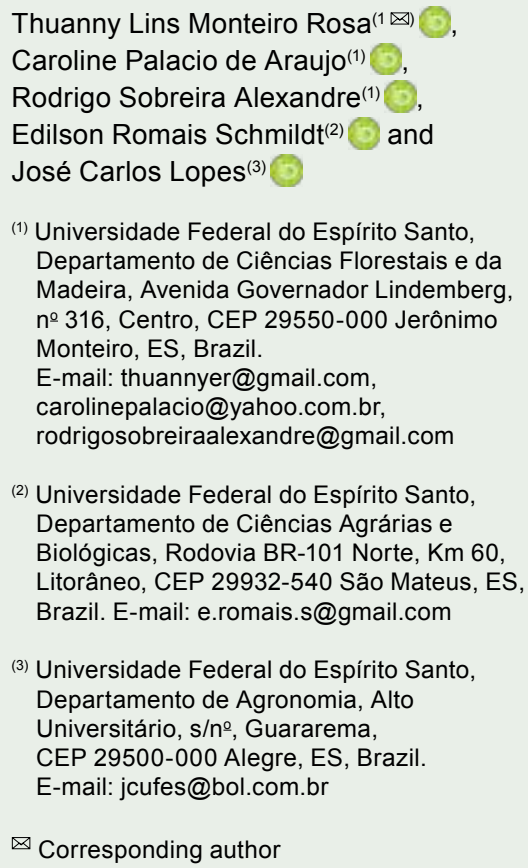

\section{Biometry and genetic diversity of paradise nut genotypes (Lecythidaceae)}

\begin{abstract}
The objective of this work was to evaluate the biometry of fruit and seed, and the diversity of paradise nut (Lecythis pisonis) genotypes. Fruit of 12 paradise nut genotypes were collected from plants in the northern region of the state of Espírito Santo and in the eastern region of the state of Minas Gerais, Brazil. Data were subjected to the analysis of variance, and means of the different genotypes were compared by Scott-Knott's mean clustering test. The phenotypic diversity was analyzed using Mahalanobis' generalized distance, and clustering, by Tocher's optimization method and the graphical dispersion of canonical variables. The relative contribution of the characters to diversity was assessed by Singh's method. The paradise nut genotypes differed regarding the morphological characteristics of fruit and seed. Genotype 1 produced the largest number of seed per fruit, and genotypes 2 and 7 produced the largest seed. These genotypes were clustered into different groups, which is indicative of their potential combination for use in genetic breeding programs.
\end{abstract}

Index terms: Lecythis pisonis, characterization, divergence, genotypes, sapucaia nut.

\section{Biometria e diversidade genética de genótipos de sapucaia (Lecythidaceae)}

Resumo - O objetivo deste trabalho foi avaliar a biometria de frutos e sementes e a diversidade de genótipos de sapucaia (Lecythis pisonis). Frutos de 12 genótipos de sapucaia foram coletados de plantas na região norte do Estado do Espírito Santo e leste do Estado de Minas Gerais. Os dados foram submetidos à análise de variância, e as médias dos diferentes genótipos foram comparadas pelo teste de agrupamento de Scott-Knott. A diversidade fenotípica foi analisada por meio da distância de Mahalanobis, e o agrupamento, pelo método de otimização de Tocher e por dispersão gráfica a partir das variáveis canônicas. A contribuição relativa das características para diversidade foi avaliada pelo método de Singh. Os genótipos de sapucaia divergiram quanto às características morfológicas de frutos e sementes. $\mathrm{O}$ genótipo 1 produziu o maior número de sementes por fruto, e os genótipos 2 e 7 produziram sementes de maiores dimensões. Esses genótipos foram separados em grupos distintos, o que é indício de sua combinação para uso em programas de melhoramento.

Termos para indexação: Lecythis pisonis, caracterização, divergência, genótipos, castanha-de-sapucaia. 


\section{Introduction}

Paradise nut (Lecythis pisonis Cambess., Lecythidaceae), is native to the Atlantic Forest and distributed in the Brazilian states from Ceará to Rio de Janeiro. The species is also found in southern Bahia and northern Espírito Santo states in Brazil (Lorenzi, 1998). Paradise nut extractivism can become an alternative in complementing the income of several producers who have these trees on their properties. The great occurrence in the mentioned regions allows of a greater gene flow that possibly generates greater genetic variability.

It has potential for timber and nontimber products, high-fruit production capacity, yielding nuts much appreciated and consumed by indigenous people (Oliveira et al., 2012). Its nuts are rich in phosphorus, magnesium, manganese, and in essential amino acids (Carvalho et al., 2012), as well as important nutritional components such as selenium (Vallilo et al., 1998). The nut also contains a peptide named L. pisonis defensin 1 (Lp-Def1), which inhibits the growth of the fungus Candida albicans that causes oral and vaginal infections in immunocompromised patients (Vieira et al., 2015). In addition to these characteristics, the species provides other benefits such as shading in cocoa plantations, in agroforestry systems, and their food resources are very attractive to wildlife (Rodrigues et al., 2015).

With all these attributes, paradise nut has a great potential to become a market competitor to Brazil nut (Bertholletia excelsa Bonpl.). The Brazil nut market between 2000 and 2010 showed growth, and the government's incentive policies for the activity were effective (Schirigatti et al., 2016). In this context, there is a great market for Brazil nut, in which other nuts can be inserted to help supply this demand, which are capable of attracting the most diverse consumers.

For a new product of plant origin to compete in the market, it is necessary to have cultivars with yield potential; therefore, studies on the species diversity and the improvement of plants are essential, by initially characterizing the materials. Paradise nut has a preferential allogamous reproductive system, in which the pollen dispersing agents are bees, and seed are dispersed by bats and humans (Mori \& Prance, 1990; Sampaio, 2000), therefore there is a need for exploiting its genetic variability, which can be measured using biometric traits of fruit and seed.
Different dissimilarity measures are used in genetic diversity studies, and the most common are the Euclidean distance and the Mahalanobis' distance $\left(\mathrm{DM}-\mathrm{D}_{\mathrm{ii}}{ }^{i}\right) . \mathrm{DM}$ is preferable, because it is estimated when the residual variance-covariance matrix is available. Then, with the dissimilarity measures, a clustering technique to discriminate individuals can be used to separate them into groups, by analyzing a set of traits inherent to each individual and classifying them in such a way that there is homogeneity within the group and heterogeneity between groups (Cruz \& Carneiro, 2003).

The genotypes can be grouped using hierarchical and optimization methods. The Tocher's optimization method considers the hypothesis that the mean dissimilarity between the genotypes clustered into the group should be less than the mean distance between any group. For graphical representation, canonical variables can be used to represent several populations in a smaller subspace. Based on a large number of correlated original traits, the analysis seeks to obtain linear combinations of these traits, named canonical variables, such that the correlation between them is null (Khattree \& Naik, 2000), aiming to provide a structural simplification of the data (Cruz et al., 2012).

The objective of this work was to evaluate the biometry of fruit and seed, and the genetic diversity of paradise nut genotypes.

\section{Materials and methods}

Initially, a dendrometric characterization of paradise nut was performed for tree height (m), diameter at $1.30 \mathrm{~m}$ from the soil $(\mathrm{cm})$, largest diameter of the crown (m), and sectional area at $1.3 \mathrm{~m}$ from the soil $\left(\mathrm{m}^{2}\right)$, in 12 matrices located in forest fragments, in the northern region of the state of Espírito Santo and in the eastern region of the state of Minas Gerais, Brazil. The location, geographic coordinates and altitude are shown in Table 1.

Fruit harvested from these 12 matrices were in an initial state of dehiscence, and they were taken to the forest seed laboratory of the Departamento de Ciências Florestais e da Madeira, at the Centro de Ciências Agrárias e Engenharias (CCAE), of Universidade Federal do Espírito Santo (UFES), in 
the municipality of Jerônimo Monteiro, in the state of Espírito Santo, Brazil.

Biometric analyses of fruit and seed were performed for: fruit length (FL, cm); largest fruit diameter $(\mathrm{D}>\mathrm{F}, \mathrm{cm})$; smallest fruit diameter $(\mathrm{D}<\mathrm{F}, \mathrm{cm})$; mean fruit diameter (MFD, $\mathrm{cm}$ ); Fruit length/largest fruit diameter ratio $(\mathrm{FL} / \mathrm{D}>\mathrm{F})$; fruit length/smallest fruit diameter ratio $(\mathrm{FL} / \mathrm{D}<\mathrm{F})$; fruit length/mean fruit diameter ratio (FL/MFD); mass of fruit with seed (MFWS, g); mass of fruit without seed (MFWOS, $\mathrm{g}$ ); number of seed per fruit (NSF); withered seed per fruit (WSF), without forming endosperm and embryo (hollow) and underdeveloped seeds; seed mass per fruit (SMF, g); 100 -seed mass (100SM, g); seed length (SL, mm); seed width (SWD, mm); seed thickness (ST, mm); seed length/seed width ratio (SL/ $\mathrm{SWD})$; and seed volume (SV, $\left.\mathrm{cm}^{3}\right)$.

Data were subjected to the analysis of variance, and means of different genotypes were compared by the Scott-Knott's clustering test.

The relative trait contributions to the phenotypic diversity was based on Singh's (1981) method, using the generalized distance of Mahalanobis. Then, the cluster analysis was performed with the Tocher's Optimization method, and scatter plots of the first two canonical variables.

All statistical analyses were performed using the Genes computational application (Cruz, 2016).

\section{Results and discussion}

Among the analyzed dendrometric characteristics in the 12 genotypes, paradise nut has shown the following: $15.14 \mathrm{~m}$ average crown diameter; $28.75 \mathrm{~m}$ height; $42.8 \mathrm{~cm}$ tree diameter, at $1.30 \mathrm{~m}$ of the soil; and $0.1458 \mathrm{~m} 2$ of sectional area at $1.30 \mathrm{~m}$ of the soil (Table 1). Many factors are involved in the rate of growth and development of a forest species, varying according to the species and within the species, which is related to genetic factors and also to the interaction with trees to their environment. These factors may affect the phenotypic characteristics of the matrix; and fast-growing species require a higher-amount of resources than slow-growing species (Chamagne et al., 2017).

The competition among trees for the same growth factors - as light, water, and nutrients - becomes evident in matrices located inside the forest fragments, due to the greater density of the vegetation (Magruder et al., 2012; Trouvé et al., 2014). Consequently, trees tend to have a more straight trunk, smaller crown diameter, and greater height growth due to the need for light to perform photosynthesis. In matrices 1 and 2 , in which the heights are the highest ones (Table 1), there were larger and heavier fruit with a higher number of less developed seed (matrix 1), and a smaller number of seed of higher weight (matrix 2) (Table 2), which is probably due to a successful competition between the trees and the surroundings, allowing of a greater

Table 1. Localization, geografic coordenates, and dendrometric characteristics of the 12 paradise nut (Lecythis pisonis) genotypes located in the states of Espírito Santo (ES) and Minas Gerais (MG), Brazil.

\begin{tabular}{|c|c|c|c|c|c|c|c|c|}
\hline \multirow{2}{*}{$\begin{array}{l}\text { Geno- } \\
\text { type }\end{array}$} & \multirow{2}{*}{$\begin{array}{c}\text { Places } \\
\text { (municipality, state) }\end{array}$} & \multicolumn{2}{|c|}{ Geographic coordenates } & \multirow{2}{*}{$\begin{array}{l}\text { Altitude } \\
\text { (m) }\end{array}$} & \multicolumn{4}{|c|}{ Characteristics } \\
\hline & & Latitude (S) & Longitude (W) & & $\mathrm{DMC}(\mathrm{m})$ & Height (m) & $\operatorname{DAP}(\mathrm{cm})$ & $\operatorname{AS}\left(\mathrm{m}^{2}\right)$ \\
\hline 1 & Linhares, ES & $19^{\circ} 26^{\prime} 01^{\prime \prime}$ & $40^{\circ} 01^{\prime} 13^{\prime \prime}$ & 26 & 15.4 & 32.8 & 41.7 & 0.13657 \\
\hline 2 & Linhares, ES & $19^{\circ} 26^{\prime} 01^{\prime \prime}$ & $40^{\circ} 01^{\prime} 13^{\prime \prime}$ & 26 & 16.5 & 33.5 & 47.0 & 0.17349 \\
\hline 3 & Linhares, ES & $19^{\circ} 26^{\prime} 01^{\prime \prime}$ & $40^{\circ} 01^{\prime} 13^{\prime \prime}$ & 26 & 18.0 & 27.0 & 50.2 & 0.19792 \\
\hline 4 & Linhares, ES & $19^{\circ} 26^{\prime} 01^{\prime \prime}$ & $40^{\circ} 01^{\prime} 13^{\prime \prime}$ & 26 & 12.5 & 24.0 & 36.6 & 0.10521 \\
\hline 5 & Linhares, ES & $19^{\circ} 29^{\prime} 46^{\prime \prime}$ & $40^{\circ} 14^{\prime} 32^{\prime \prime}$ & 27 & 16.0 & 29.2 & 53.4 & 0.22396 \\
\hline 6 & Linhares, ES & $19^{\circ} 29^{\prime} 46^{\prime \prime}$ & $40^{\circ} 14^{\prime} 32^{\prime \prime}$ & 27 & 14.4 & 31.5 & 43.7 & 0.14998 \\
\hline 7 & Linhares, ES & $19^{\circ} 29^{\prime} 46^{\prime \prime}$ & $40^{\circ} 14^{\prime} 32^{\prime \prime}$ & 27 & 17.2 & 25.6 & 38.1 & 0.11401 \\
\hline 8 & Linhares, ES & $19^{\circ} 30^{\prime} 03^{\prime \prime}$ & $40^{\circ} 16^{\prime} 39^{\prime \prime}$ & 39 & 15.8 & 27.0 & 40.6 & 0.12946 \\
\hline 9 & Linhares, ES & $19^{\circ} 30^{\prime} 03^{\prime \prime}$ & $40^{\circ} 16^{\prime} 39^{\prime \prime}$ & 39 & 17.0 & 30.5 & 43.2 & 0.14657 \\
\hline 10 & Baixo Guandu, ES & $19^{\circ} 23^{\prime} 55^{\prime \prime}$ & $40^{\circ} 57^{\prime} 11^{\prime \prime}$ & 533 & 11.5 & 29.5 & 36.8 & 0.10636 \\
\hline 11 & Baixo Guandu, ES & $19^{\circ} 23^{\prime} 38^{\prime \prime}$ & $40^{\circ} 56^{\prime} 53^{\prime \prime}$ & 518 & 14.9 & 28.0 & 41.9 & 0.13788 \\
\hline 12 & Itueta, MG & $19^{\circ} 23^{\prime} 15^{\prime \prime}$ & $41^{\circ} 03 ' 34^{\prime \prime}$ & 168 & 13.5 & 26.5 & 40.4 & 0.12819 \\
\hline
\end{tabular}

DMC, larger diameter of the crown; DAP, diameter of the tree, at $1.30 \mathrm{~m}$ above the soil surface; AS, sectional area, at $1.30 \mathrm{~m}$ above the soil surface. 


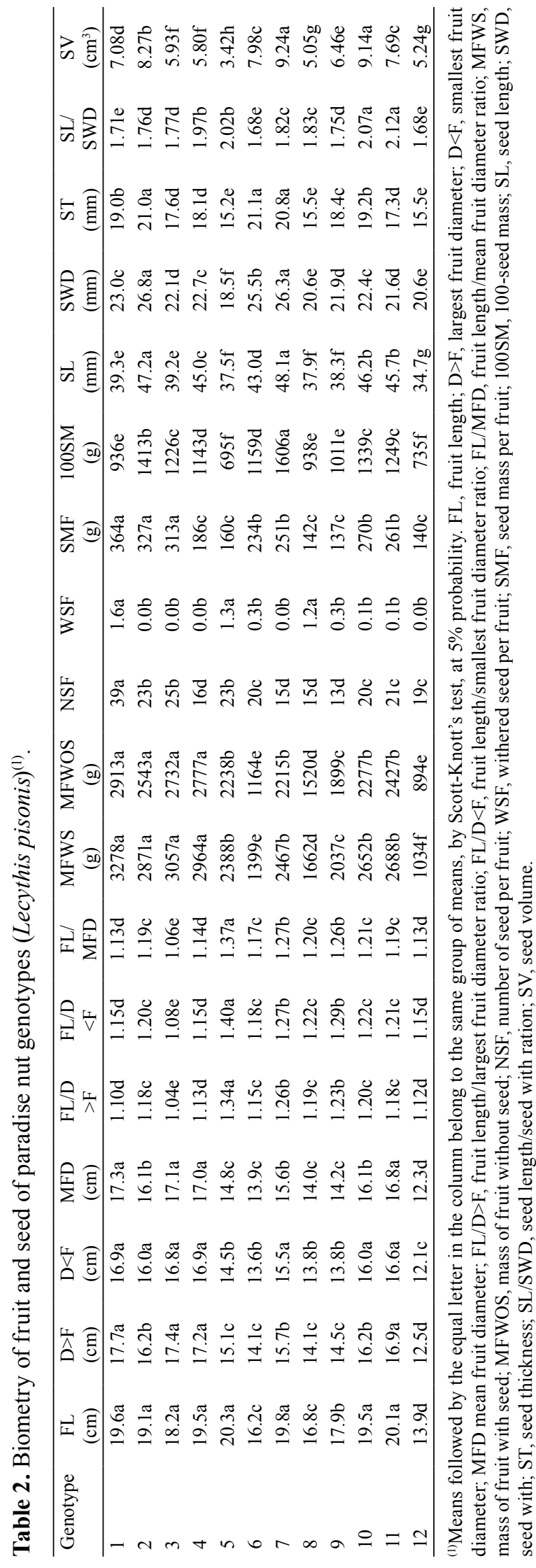

exposure of the canopy to sunlight, which caused the increase of the photosynthetic activity and the greater accumulation of photoassimilates for fruit production. Another strategy that increases the photosynthetic activity and consequently the accumulation of photoassimilates is the increase of crown diameter, observed in matrix 7 (Table 1), which produced more developed seed (Table 2).

In Pinus taeda cultivations of greater density the diameter of trunk and crowns tend to be smaller than in plantations of lower densities (Akers et al., 2013). The production may also be affected when considering the phenotypic characteristics, as observed by Klimas et al. (2012) in trees of Carapa guianensis, which produced larger amounts of seed when the diameter of the tree, at 1.30 of the soil (DAP), was between $40-50 \mathrm{~cm}$, and higher values promoted a reduction of the production.

The biometric analyses of fruit and seed of the 12 genotypes of paradise nut identified genetic materials that produce larger and heavier fruit (GEN 1, 3278 g; GEN 3, 3057.8 g; and GEN 4, 2964 g) and smaller and lighter fruit (GEN 12, $1034 \mathrm{~g}$; GEN 6, $1399.1 \mathrm{~g}$; and GEN 8, $1662.7 \mathrm{~g}$ ) (Table 2). Fruit are strong sinks and when larger in the mother plant, they show the vigor of these genetic materials in producing chemical constituents at greater amounts for their formation and seed. The size of a paradise nut fruit may be related to its greater internal space which allows of the storage of a larger number of less developed seed (GEN 1), or of a smaller number of more developed seed (GENs 2 and 7) (Table 2). Souza et al. (2008) found 445.53 $\mathrm{g}$ mean fruit mass, and classified them as small ( $F M<1,100 \mathrm{~g})$, medium $(1,300 \mathrm{~g}<\mathrm{FM}<1,500 \mathrm{~g})$, large $(1,600 \mathrm{~g}<\mathrm{FM}<1,900 \mathrm{~g})$, and extra-large ( $\mathrm{FM}>2,000 \mathrm{~g})$. According to this classification, GENs 1, 2, 3, 4, 5, 7, 9, 10 , and 11 are considered extra-large (75\%), and GEN 8 is large, GEN 6 is medium, and GEN 12 is small (Table 2), totaling $25 \%$.

The mean number of seed produced per paradise nut fruit, in the 12 GENs, was 21 . GEN 1, with extralarge fruit, produced the highest number of seed per fruit (39.5 seed, but these were less developed seed), a difference of 24 seed in relation to the less productive GENs (GEN 4, 16.2; GEN 7, 15.7; GEN 8, 15.2; and GEN 9, 13.6 seed), which corresponds to $38.4 \%$ less in seed production. Souza et al. (2008) reported 21 seed in sap fruit. Brazil nut (B. excelsa) had mean number of 15 seed in eight individuals of this species, with 
a maximum of 24 seed, and a minimum of 14 ones (Tonini, 2013). Species of the family Lecythidaceae have different number and dimension (length- $\mathrm{L} x$ width-W) of seed per fruit: Lecythis poiteaui O. Berg (4-6 seed); B. excelsa (up to $25 \mathrm{seed}, 3.5-5.0 \times 2.0 \mathrm{~cm}$ LxW); Couratari tenuicarpa A.C. Sm. (3.5-4 x 1.2$1.5 \mathrm{~cm}$ LxW); Eschweilera amazonica R. Knuth (1-4 seed); Eschweilera tenuifolia (O. Berg) Miers (30-50 seed, 2-2.7 x 0.8-1.3 cm LxW); Eschweilera truncata A.C. Sm. (2 seed, 1.8-2.0 x 1.4-1.5 cm LxW) (Matta \& Scudeller, 2012); Gustavia augusta L. (0.13 x $0.10 \mathrm{~cm}$ LxW) (Silva et al., 2014); and Eschweilera compressa (Vell.) Miers (6-10 seed; 2.2-3.3 × 1.6-2 cm LxW) (Ribeiro et al., 2016). The production of fruit and seed of B. excelsa varies between populations and individuals, and most of them do not produce fruit every year. In a year of great production, a Brazil nut stand produces 52 times more than in low-production years (Tonini $\&$ Pedroso, 2014). The B. excelsa trees bearing fruit had significantly larger crown area than unproductive ones (Scoles et al., 2016), which is related to a greater photosynthetically active area that resulted in more productive genotypes with superior fruit quality.

Paradise nut fruit showed a shape variation among GENs from the most oblong (GEN 5) to the most circular one (GEN 3) (Table 2). Seed of the genotype with the smallest fruit (GEN 5) were $37.5 \mathrm{~mm}$ long, $18.5 \mathrm{~mm}$ wide, and $15.2 \mathrm{~mm}$ thick (GEN 5); and seed of the genotypes with the largest fruit (GENs 2 and 7) were $47.2 \mathrm{~mm}$ long, $26.8 \mathrm{~mm}$ wide, and $21.0 \mathrm{~mm}$ thick (GEN 2), and $48.1 \mathrm{~mm}$ long, $26.3 \mathrm{~mm}$ wide, and $20.8 \mathrm{~mm}$ thick (GEN 7) (Table 2). Souza et al. (2008) reported for paradise nut $2.27 \mathrm{~g}$ seed mass, $2.35 \mathrm{~cm}$ length, $1.4 \mathrm{~cm}$ diameter, and 1.68 length/diameter ratio. Paradise nut seed are not commercialized yet, therefore, some important characteristics of it should be analyzed, such as biometrics (dimensions and shape), nutritional and functional elements such as selenium. Also, market trends for this nut acceptance regarding flavor and other organoleptic characteristics should be investigated, to meet consumer quality standards. In this respect, paradise nut seed can be closer to the spherical shape (GEN 1) or show a more elongated shape (GEN 10 and 11) (Table 2), and the last two genotypes have seed shape similar to that of Brazil nut (B. excelsa, Lecythidaceae). Seed of paradise nut stand out for having higher-mean diameter, length and weight than other species (Sterculia striata and
Dipteryx spp.) of the same Lecythidaceae family (Carvalho et al., 2008).

The size of paradise nut seed is related to their mass and, consequently, to the amount of nutrients, particularly selenium, that involves the necessary quantity of this element to be supplied daily to the consumer. In this sense, a study reported that people aged approximately 77 years, who had consumed Brazil nuts for six months (288.75 $\mu$ g per day), showed positive effects on some cognitive functions, with improvements of verbal fluency (Cardoso et al., 2016).

Moreover, larger seed have an important relation with the plant sexual propagation, since they store a quantity of reserve crucial for embryo development during germination and for survival in the field. Penoni et al. (2011) also observed a good seedling development in macadamia cultivars, with highkernel mass. Reserve constituents in paradise nut seed influence the mode of dispersal of the species in the environment. Nuts are usually dispersed by mammals; for instance, $B$. excelsa nuts are buried by rodents, so they can consume them later, but these nuts are often forgotten after they have chewed their shell, which is an important factor in maintaining this species in the natural environment (Haugaasen et al., 2012).

Table 3. Relative contribution of traits to the diversity of paradise nut (Lecythis pisonis) genotypes, by Singh's (1981) criterion based on the distance (D2) of Mahalanobis.

\begin{tabular}{lcc}
\hline Variable & D2 (S.j) & Value (\%) \\
\hline Fruit length & 150.5348 & 0.68 \\
Larger fruit diameter & 1180.4178 & 5.33 \\
Smaller fruit diameter & 1834.0261 & 8.28 \\
Mean fruit diameter & 2430.3227 & 10.98 \\
Fruit length/larger fruit diameter ratio & 99.9090 & 0.45 \\
Fruit length/smaller fruit diameter ratio & 638.5413 & 2.88 \\
Fruit length/mean fruit diameter ratio & 844.4246 & 3.81 \\
Number of seed per fruit & 1061.0421 & 4.79 \\
Mass of fruit with seed & 158.6394 & 0.71 \\
Mass of fruit without seed & 1034.1256 & 4.67 \\
Seed mass per fruit & 236.8680 & 1.07 \\
Withered seed per fruit & 76.1469 & 0.34 \\
Seed length & 2073.8018 & 9.37 \\
Seed width & 5498.3528 & 24.84 \\
Seed thickness & 1162.4949 & 5.25 \\
100-seed mass & 662.6315 & 2.99 \\
Seed length/seed width ratio & 110.5516 & 0.49 \\
Seed volume & 2877.6201 & 13.00 \\
\hline
\end{tabular}


The traits that contributed most to the genetic diversity of the paradise nut genotypes were seed width and seed volume (Table 3 ). Width and volume of the seed are morphological characteristics simple to be analyzed. Width is important to form the nut shape, and both width and volume are indicators of development. The nut size is related to the amount of substances contained in it (minerals, such as selenium, and proteins, lipids, and vitamins), which influences its daily consumption by people. The recommendation for consumption may be one, two, or more nuts.

The genotypes were clustered into six groups: group I, GENs 3, 8, 9, and 12; group II, GENs 10 and 11; group III, GENs 2, 6 and 7; group IV, GEN 1; group V, GEN 4; and group VI, GEN 5 (Table 4). GEN 1, which produced the highest number of seed per fruit, and GENs 2 and 7, which produced the largest seed, were clustered into different groups. These genotypes can be used in breeding programs.

The first two canonical variables explained $79.64 \%$ of the total variation $(65.98 \%$ the first one, and $13.66 \%$ the second one). The canonical variables pointed out to the formation of six groups: group I, GEN 5; group II, GENs 3, 8, 9, and 12; group III, GEN 4; group IV, GEN 1; group V, GENs 10 and 11; and group VI, GENs 2, 6, and 7 (Figure 1). The same group formation was confirmed by both the Tocher's method, based on the generalized distance of Mahalanobis (Table 4), and the canonical variables (Figure 1), for the biometric characteristics of fruit and seed of paradise nut genotypes. In a diversity study of Casearia grandiflora (Salicaceae), both the main component analysis and the clustering methods showed similarities in the clustering of the plants, which contributed to the knowledge of the phenotypic

Table 4. Clustering of paradise nut (Lecythis pisonis) genotypes, using 18 characteristics of fruit and seed, based on the Tocher's optimization method and Mahalanobis generalized distance.

\begin{tabular}{lc}
\hline Groups & Genotypes \\
\hline I & $3,8,9,12$ \\
II & 10,11 \\
III & $2,6,7$ \\
IV & 1 \\
V & 4 \\
VI & 5 \\
\hline
\end{tabular}

variation and divergence patterns of the species (Costa et al., 2016). In the present study, there was a large group separation due to their heterogeneity, which is of interest for breeding programs using distant genotypes. According to Rodrigues et al. (2015), the observed and expected heterozygosity values in 40 paradise nut genotypes were, on average, 0.687 and 0.856, respectively. Cruz \& Regazzi (2001) pointed out that a greater heterozygosity allows of a more likely identification of superior genotypes in the segregating generations. In Brazil nut, the absence of inbreeding supports the existence of mechanisms of self-incompatibility and selection in favor of heterozygotes. In addition, the maintenance of genetic variability is favored by the allogamous reproduction, which is an important characteristic to be considered in conservation (Sujii et al., 2011, 2015).

Nondestructive measurements such as fruit length showed a strong correlation with mass of fruit with seed (Table 5); fruit diameters showed a very strong correlation with mass of fruit with seed $\left[\mathrm{D}>\mathrm{F}\right.$ vs. MFWS $\left(\mathrm{rf}=0.969^{* *}\right), \mathrm{D}<\mathrm{F}$ vs. MFWS ( $\mathrm{rf}$ $\left.=0.959^{* *}\right)$, and MFD vs. MFWS $\left.\left(\mathrm{rf}=0.965^{* *}\right)\right]$, and strong correlation with seed mass per fruit $[\mathrm{D}>\mathrm{F}$ vs. SMF $\left(\mathrm{rf}=0.734^{* *}\right), \mathrm{D}<\mathrm{F}$ vs. SMF $\left(\mathrm{rf}=0.736^{* *}\right)$, and MFD vs. SMF $\left.\left(\mathrm{rf}=0.737^{* *}\right)\right]$, according to Carvalho et al. (2004). These results indicate that lengthier fruit show a greater mass of fruit with seed, and fruit with larger diameters have a greater mass of fruit with seed and greater seed mass per fruit,

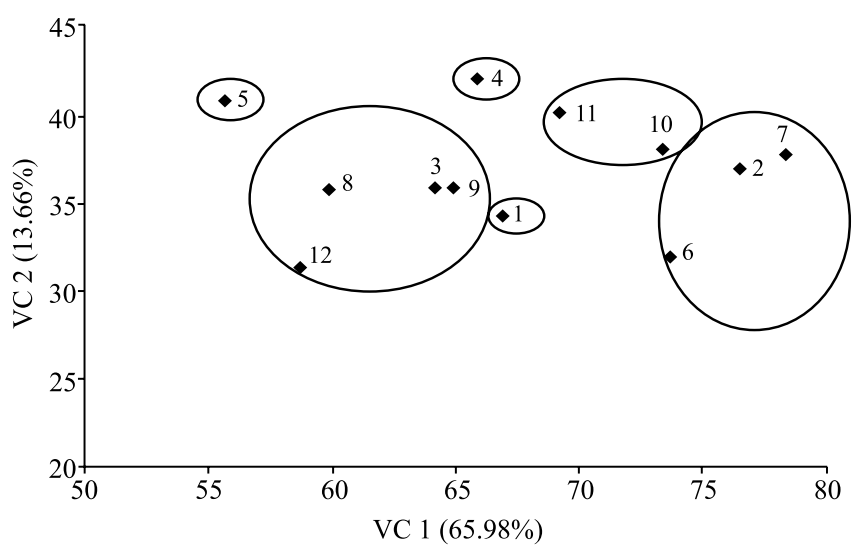

Figure 1. Graphical dispersion of the first two canonical variables of 12 paradise nut (Lecythis pisonis) genotypes, for the biometric characteristics of fruit and seed. 


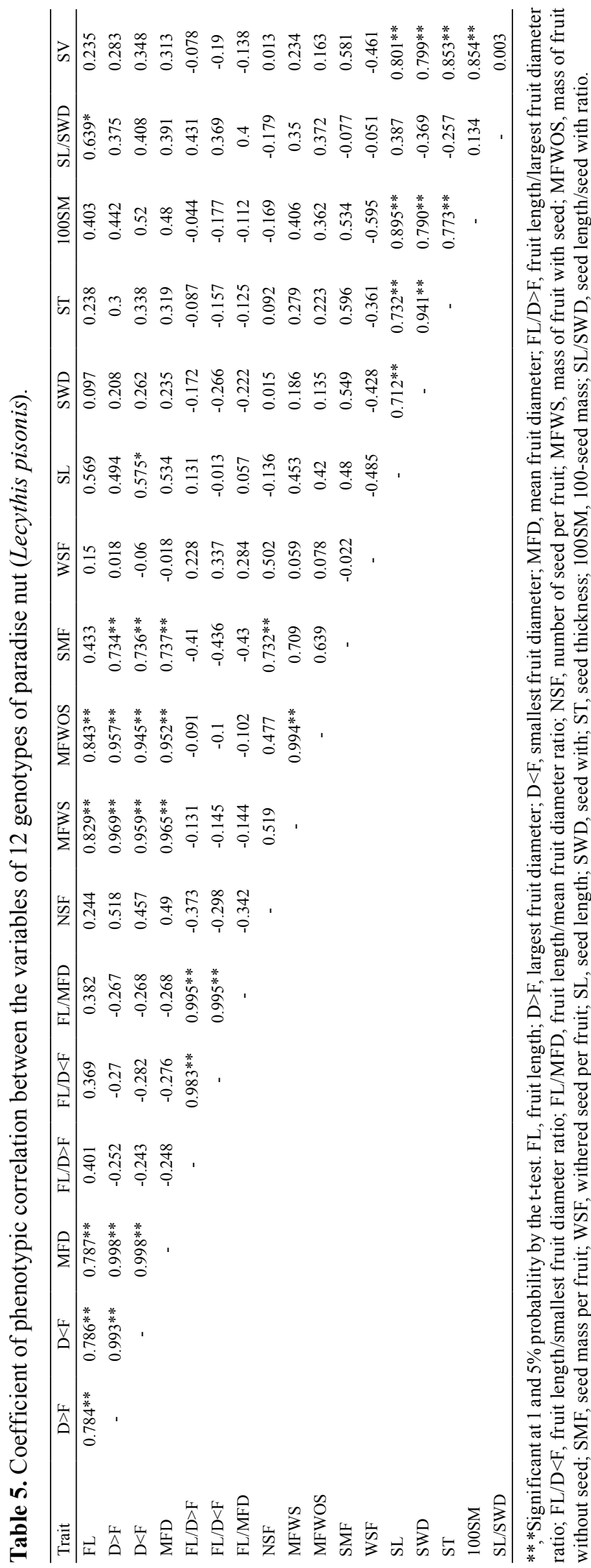

which are important characteristics for the selection of superior genotypes of paradise nut in breeding programs. Teixeira et al. (2015) found a very strong correlation between the mass of fruit with seed and the transverse $\left(\mathrm{Rf}=0.9637^{* *}\right)$ and longitudinal $(\mathrm{rf}=$ $\left.0.9374^{* *}\right)$ circumferences of Brazil nut fruit. Moura et al. (2013) reported (.) a strong correlation between the transverse fruit diameter and the number of pyrenes per fruit of Caryocar brasiliense Camb., which is related to the yield of pyrene per fruit.

\section{Conclusions}

1. The twelve paradise nut genotypes diverge for their morphological characteristics of fruit and seed.

2. Genotype 1 produces the largest number of seed per fruit, and genotypes 2 and 7 produce the largest seed; these genotypes are clustered into distinct groups, which is indicative of their combination in paradise nut breeding programs.

\section{Acknowledgments}

To Coordenação de Aperfeiçoamento de Pessoal de Nível Superior (Capes, Finance Code 001), for financial support and to Conselho Nacional de Desenvolvimento Científico e Tecnológico (CNPq), for an award for excellence in research.

\section{References}

AKERS, M.K.; KANE, M.;ZHAO, D.; TESKEY, R.O.; DANIELS, R.F. Effects of planting density and cultural intensity on stand and crown attributes of mid-rotation loblolly pine plantations. Forest Ecology and Management, v.310, p.468-475, 2013. DOI: https:// doi.org/10.1016/j.foreco.2013.07.062.

CARDOSO, B.R.; APOLINÁRIO, D.; BANDEIRA, V. da S.; BUSSE, A.L.; MAGALDI, R.M.; JACOB-FILHO, W.; COZZOLINO, S.M.F. Effects of Brazil nut consumption on selenium status and cognitive performance in older adults with mild cognitive impairment: a randomized controlled pilot trial. European Journal of Nutrition, v.55, p.107-116, 2016. DOI: https://doi.org/10.1007/s00394-014-0829-2.

CARVALHO, M.G. de; COSTA, J.M.C. da; SOUZA, V.A.B. de; MAIA, G.A. Avaliação dos parâmetros físicos e nutricionais de amêndoas de chichá, sapucaia e castanha-do-gurguéia. Revista Ciência Agronômica, v.39, p.517-523, 2008.

CARVALHO, I.M.M. de; QUEIRÓS, L.D.; BRITO, L.F.; SANTOS, F.A.; BANDEIRA, A.V.M.; SOUZA, A.L. de; QUEIROZ, J.H. de. Caracterização química da castanha de 
sapucaia (Lecythis pisonis Cambess.) da região da zona da mata mineira. Bioscience Journal, v.28, p.971-977, 2012.

CARVALHO, F.I.F. de; LORENCETTI, C.; BENIN, G. Estimativas e implicações da correlação no melhoramento vegetal. Pelotas: Ed. da UFPel, 2004. 141p.

CHAMAGNE, J.; TANADINI, M.; FRANK, D.; MATULA, R.; PAINE, C.E.T.; PHILIPSON, C.D.; SVÁTEK, M.; TURNBULL, L.A.; VOLAŘÍK, D.; HECTOR, A. Forest diversity promotes individual tree growth in central European forest stands. Journal of Applied Ecology, v.54, p.71-79, 2017. DOI: https://doi. org/10.1111/1365-2664.12783.

COSTA, M.F.; LOPES, A.C. de A.; GOMES, R.L.F.; ARAÚJO, A.S.F. de; ZUCCHI, M.I.; PINHEIRO, J.B.; VALENTE, S.E. dos S. Caracterização e divergência genética de populações de Casearia grandiflora no cerrado piauiense. Floresta e Ambiente, v.23, p.387-396, 2016. DOI: https://doi.org/10.1590/2179-8087.007115.

CRUZ, C.D. Genes Software-extended and integrated with the R, Matlab and Selegen. Acta Scientiarum. Agronomy, v.38, p.547552, 2016. DOI: http://doi.org/10.4025/actasciagron.v38i4.32629.

CRUZ, C.D.; CARNEIRO, P.C.S. Modelos biométricos aplicados ao melhoramento genético. Viçosa: Ed. da UFV, 2003. v.2, 585p.

CRUZ, C.D.; REGAZZI, A.J. Modelos biométricos aplicados ao melhoramento genético. 2.ed. Viçosa: Ed. da UFV, 2001. 390p.

CRUZ, C.D.; REGAZZI, A.J.; CARNEIRO, P.C.S. Modelos biométricos aplicados ao melhoramento genético. 4.ed. Viçosa: Ed. da UFV, 2012. v.1, 514p.

HAUGAASEN, J.M.T; HAUGAASEN, T.; PERES, C.A.; GRIBEL, R.; WEGGE, P. Fruit removal and natural seed dispersal of the Brazil nut tree (Bertholletia excelsa) in Central Amazonia, Brazil. Biotropica, v.44, p.205-210, 2012. DOI: https://doi.org/10.1111/j.1744-7429.2011.00796.x.

KHATTREE, R.; NAIK, D.N. Multivariate data reduction and discrimination with SAS software. [S.1.]: SAS Publishing, 2000. $584 \mathrm{p}$.

KLIMAS,C.A.;KAINER,K.A.;WADT,L.H.;STAUDHAMMER, C.L.; RIGAMONTE-AZEVEDO, V.; CORREIA, M.F.; LIMA, L.M. da S. Control of Carapa guianensis phenology and seed production at multiple scales: a five-year study exploring the influences of tree attributes, habitat heterogeneity and climate cues. Journal of Tropical Ecology, v.28, p.105-118, 2012. DOI: https://doi.org/10.1017/S0266467411000630.

LORENZI, H. Árvores brasileiras: manual de identificação e cultivo de plantas arbóreas nativas do Brasil. 2.ed. Nova Odessa: Plantarum, 1998. v.2, 352p.

MAGRUDER, M.; CHHIN, S.; MONKS, A.; O'BRIEN, J. Effects of initial stand density and climate on red pine productivity within Huron National Forest, Michigan, USA. Forests, v.3, p.1086-1103, 2012. DOI: https://doi.org/10.3390/f3041086.

MATTA, L.B.V.; SCUDELLER, V.V. Lecythidaceae Poit. in the Tupé Sustainable Development Reserve, Manaus, Brazil. Brazilian Journal of Botany, v.35, p.195-217, 2012. DOI: https://doi.org/10.1590/S1806-99592012000200008.

MORI, S.A.; PRANCE, G.T. Lecythidaceae: Part II: the zygomorphic-flowered New World genera (Couroupita,
Corythophora, Bertholletia, Couratari, Eschweilera, \& Lecythis). New York: The New York Botanical Garden, 1990. 375p. (Flora Neotropica. Monograph, 21, II). With a study of secondary xylem of Neotropical Lecythidaceae by Carl H. de Zeeuw.

MOURA, N.F.; CHAVES, L.J.; NAVES, R.V. Caracterização física de frutos de pequizeiro (Caryocar brasiliense Camb.) do cerrado. Revista Árvore, v.37, p.905-912, 2013. DOI: https://doi.org/10.1590/S0100-67622013000500013.

OLIVEIRA, V.B.; YAMADA, L.T.; FAGG, C.W.; BRANDÃO, M.G.L. Native foods from Brazilian biodiversity as a source of bioactive compounds. Food Research International, v.48, p.170179, 2012. DOI: https://doi.org/10.1016/j.foodres.2012.03.011.

PENONI, E. dos S.; PIO, R.; RODRIGUES, F.A.; MARO, L.A.C.; COSTA, F.C. Análise de frutos e nozes de cultivares de nogueiramacadâmia. Ciência Rural, v.41, p.2080-2083, 2011. DOI: https://doi.org/10.1590/S0103-84782011001200007.

RIBEIRO, M.; MORI, S.A.; ALVES-ARAÚJO, A.; SIQUEIRA, G. de S.; PEIXOTO, A.L. Eschweilera compressa (Vell.) Miers (Lecythidaceae): a new record of a threatened plant species in Espírito Santo state, Brazil. Check List, v.12, art.1994, 2016. DOI: https://doi.org/10.15560/12.6.1994.

RODRIGUES, A.B.; FLORENCE, C.T.; MARIANO-NETO, E.; GAIOTTO, F.A. First microsatellite markers for Lecythis pisonis (Lecythidaceae), an important resource for Brazilian fauna. Conservation Genetics Resources, v.7, p.437-439, 2015. DOI: https://doi.org/10.1007/s12686-014-0390-6.

SAMPAIO, P. de T.B. Castanha-sapucaia (Lecythis pisonis). In: CLAY, J.W.; SAMPAIO, P. de T.B.; CLEMENT, C.R. (Ed.). Biodiversidade amazônica: exemplos e estratégias de utilização. Manaus: INPA: SEBRAE-AM, 2000. p.141-147.

SCHIRIGATTI, E.L.; AGUIAR, G.P.; SILVA, J.C.G.L. da; FREGA, J.R.; ALMEIDA, A.N. de; HOEFLICH, V.A. Market behavior for in shell Brazil nuts produced in Brazil from 2000 to 2010. Floresta e Ambiente, v.23, p.369-377, 2016. DOI: https://doi.org/10.1590/2179-8087.075614.

SCOLES, R.; CANTO, M.S.; ALMEIDA, R.G.; VIEIRA, D.P. Sobrevivência e frutificação de Bertholletia excelsa Bonpl. em áreas desmatadas em Oriximiná, Pará. Floresta e Ambiente, v.23, p.555-564, 2016. DOI: https://doi.org/10.1590/2179-8087.132015.

SILVA, R.M. da; RIBEIRO, R. de T.M.; COUTINHO, D.J.G.; SILVA, S.I. da; GALLÃO, M.I. Caracterização de frutos, sementes, plântulas e germinação de Jeniparana. Revista Ceres, v.61, p.746-751, 2014. DOI: https://doi.org/10.1590/0034737X201461050019.

SINGH, D. The relative importance of characters affecting genetic divergence. Indian Journal of Genetics and Plant Breeding, v.41, p.237-245, 1981.

SOUZA, V.A.B. de; CARVALHO, M.G. de; SANTOS, K.S.; FERREIRA, C. da S. Características físicas de frutos e amêndoas e características químico-nutricionais de amêndoas de acessos de sapucaia. Revista Brasileira de Fruticultura, v.30, p.946-952, 2008. DOI: https://doi.org/10.1590/S0100-29452008000400018.

SUJII, P.; MARTINS, K.; WADT, L.; AZEVEDO, V.; SOLFERINI, V. Genetic diversity of Bertholletia excelsa, an 
Amazonian species of wide distribution. BMC Proceedings, v.5, P5, 2011. Suppl 7. DOI: https://doi.org/10.1186/1753-6561-5-S7-P5.

SUJII, P.S.; MARTINS, K.; WADT, L.H. de O.; AZEVEDO, V.C.R.; SOLFERINI, V.N. Genetic structure of Bertholletia excelsa populations from the Amazon at different spatial scales. Conservation Genetics, v.16, p.955-964, 2015. DOI: https://doi.org/10.1007/s10592-015-0714-4.

TEIXEIRA, R.A.; PEDROZO, C.A.; COSTA, E.K.L. da; BATISTA, K.D.; TONINI, H.; PESSONI, L.A. Correlações e divergência fenotípica entre genótipos cultivados de castanha-doBrasil. Scientia Forestalis, v.43, p.523-531, 2015.

TONINI, H. Amostragem para a estimativa de produção de sementes de castanheira-do-brasil em floresta nativa. Pesquisa Agropecuária Brasileira, v.48, p.519-527, 2013. DOI: https://doi.org/10.1590/S0100-204X2013000500008.

TONINI, H.; PEDROZO, C.Â. Variações anuais na produção de frutos e sementes de castanheira-do-brasil (Bertholletia excelsa Bonpl., Lecythidaceae) em florestas nativas de Roraima. Revista
Árvore, v.38, p.133-144, 2014. DOI: https://doi.org/10.1590/ S0100-67622014000100013.

TROUVÉ, R.; BONTEMPS, J.-D.; COLLET, C.; SEYNAVE, I.; LEBOURGEOIS, F. Growth partitioning in forest stands is affected by stand density and summer drought in sessile oak and Douglas-fir. Forest Ecology and Management, v.334, p.358-368, 2014. DOI: https://doi.org/10.1016/j.foreco.2014.09.020.

VALLILO, M.I.; TAVARES, M.; PIMENTEL, S.A.; BADOLATO, E.S.G.; INOMATA, E.I. Caracterização química parcial das sementes de Lecythis pisonis Camb. (sapucaia). Acta Amazonica, v.28, p.131-140, 1998. DOI: https://doi.org/10.1590/180943921998282140.

VIEIRA, M.E.B.; VASCONCELOS, I.M.; MACHADO, O.L.T.; GOMES, V.M.; CARVALHO, A. de O. Isolation, characterization and mechanism of action of an antimicrobial peptide from Lecythis pisonis seeds with inhibitory activity against Candida albicans. Acta Biochimica et Biophysica Sinica, v.47, p.716-729, 2015. 